\title{
Evolution of membrane oxygenator technology for utilization during pediatric cardiopulmonary
} bypass

\author{
Richard W Melchior' \\ Steven W Sutton ${ }^{2}$ \\ William Harris ${ }^{3}$ \\ Heidi J Dalton ${ }^{4,5}$ \\ 'Department of Perfusion \\ Services, The Children's Hospital \\ of Philadelphia, Philadelphia, PA, \\ ${ }^{2}$ Cardiovascular Support Services, Inc., \\ Dallas, TX, ${ }^{3}$ Department of Perfusion \\ Services, Ochsner Clinic Foundation, \\ New Orleans, LA, ${ }^{4}$ Alaskan Native \\ Tribal Health Consortium, Anchorage, \\ AK, ${ }^{5}$ Department of Child Health, \\ University of Arizona-College of \\ Medicine, Phoenix, AZ, USA
}

This article was published in the following Dove Press journal:

Pediatric Health, Medicine and Therapeutics

28 June 2016

Number of times this article has been viewed

\begin{abstract}
The development of the membrane oxygenator for pediatric cardiopulmonary bypass has been an incorporation of ideology and technological advancements with contributions by many investigators throughout the past two centuries. With the pursuit of this technological achievement, the ability to care for mankind in the areas of cardiac surgery has been made possible. Heart disease can affect anyone within the general population, but one such segment that it can affect from inception includes children. Currently, congenital heart defects are the most common birth defects nationally and worldwide. A large meta-analysis study from 1930 to 2010 was conducted in review of published medical literature totaling 114 papers with a study population of 24,091,867 live births, and divulged a staggering incidence of congenital heart disease involving 164,396 subjects with diverse cardiac illnesses. The prevalence of these diseases increased from 0.6 per 1,000 live births from 1930-1934 to 9.1 per 1,000 live births after 1995. These data reveal an emphasis on a growing public health issue regarding congenital heart disease. This discovery displays a need for heightened awareness in the scientific and medical industrial community to accelerate investigative research on emerging cardiovascular devices in an effort to confront congenital anomalies. One such device that has evolved over the past several decades is the pediatric membrane oxygenator. The pediatric membrane oxygenator, in conjunction with the heart lung machine, assists in the repair of most congenital cardiac defects. Numerous children born with congenital heart disease with or without congestive heart failure have experienced improved clinical outcomes in quality of life, survival, and mortality as a result of the inclusion of this technology during their cardiac surgical procedure. The purpose of this review is to report a summary of the published medical and scientific literature related to development of the pediatric membrane oxygenator from its conceptual evolutionary stages to artificially supporting whole body perfusion in the modern pediatric cardiac surgical setting.
\end{abstract}

Keywords: cardiovascular perfusion, pediatric cardiac surgery, extracorporeal technological advancement

\section{Introduction}

"I shall shortly further try, whether the suffering the Blood to circulate through a vessel, so as it may be openly exposed to fresh air, will not suffice for the life of an Animal; and make some other Experiments, which, I hope, will thoroughly discover the Genuine use of Respiration; and afterwards consider what benefit this may be to Mankind." (Robert Hooke, 1667). ${ }^{1}$

This 17 th century quote by Hooke marks the commencement of investigative research into extracorporeal circulation and the eventual development of all components of the perfusion circuit necessary to safely oxygenate blood artificially.
Correspondence: Richard W Melchior The Children's Hospital of Philadelphia, The Cardiac Center, 34th Street and Civic Center Blvd, Philadelphia, PA 19104, USA

Email melchiorr@email.chop.edu (c) (7) (5) 2016 Melchior et al. This work is published and licensed by Dove Medical Press Limited. The full terms of this license are available at https://www.dovepress.com/terms. cc. you hereby accept the Terms. Non-commercial uses of the work are permitted without any further permission from Dove Medical Press Limited, provided the work is properly attributed. For permission for commercial use of this work, please see paragraphs 4.2 and 5 of our Terms (https://www.dovepress.com/terms.php). 
Many physiology laboratories worldwide have participated and contributed to the process of developing extracorporeal circulation which, at its inception, was only capable of supporting isolated organs for a brief period. Beginning in the late 19th century, researchers made tremendous strides, transitioning from the conceptualization period of Robert Hooke in 1667 and Le Gallois in 1812 (Figure 1) to presentday reality. ${ }^{1,2}$

"If one could substitute for the heart a kind of injection ... of arterial blood, either natural or artificially made ... one would succeed easily in maintaining alive indefinitely any part of the body." (Le Gallois 1812). ${ }^{2}$

The resources initially utilized to develop extracorporeal technology were restricted to common items found in a biochemistry laboratory, consisting of glass containers and rubber bladders functioning as blood reservoirs. Syringe injectionstyled transfusion pumps equipped with nothing more than a plunger served as the perfusion device (Figure 1). Scientific research methodically investigated the physiological responses of limbs and major organ structures to external artificial circulation. It took 140 years to advance this technology from the experimental laboratory to the operative setting for implementation as a modality of treatment for humans, namely children presenting with congenital heart disease (Figure 2).

Currently, congenital heart defects are the most common birth defect nationally and worldwide. ${ }^{3}$ To illustrate the magnitude of the public health crisis concerning congenital heart disease, a meta-analysis study was published in 2011. van der Linde et al revealed data involving 24,091,867 live births. They analyzed 114 published papers and showed epidemiological findings for 164,396 subjects with congenital heart disease grouped in 5-year interval time periods from 1930 to 2010 . This study showed that 1.35 million live births

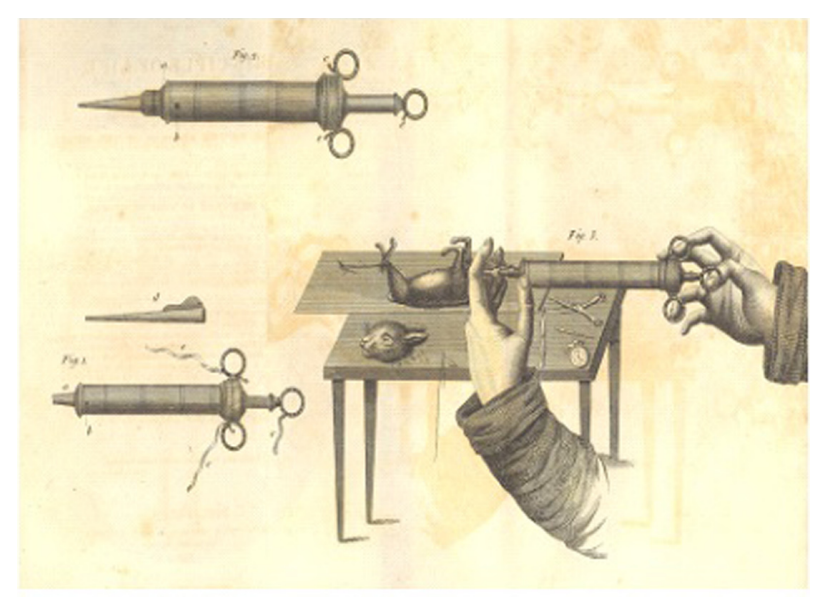

Figure I Early methods to investigate perfusion science. ${ }^{2}$ (of 150 million annual live births worldwide) had congenital heart disease. ${ }^{4}$ This study showed the need to further develop pediatric membrane oxygenator technology to assist in improving survivability from surgical treatment of heart disease in children.

The development of the "ideal" oxygenator has tried to find a balance between biocompatibility as a non-inflammatory unit and atraumatic cellular characteristics with respect to the blood and formed elements. Historically, many devices were introduced to find this balance, including rotating disc, screen, film, and bubble oxygenators. ${ }^{5-11}$ At the beginning of open heart surgery, which included cardiopulmonary bypass (CPB), there were unfortunately several failed attempts (Table 1). ${ }^{12-22}$ As technology advanced, the bubble oxygenator device introduced by DeWall and Lillehei emerged as the safest and most cost-efficient disposable system worldwide. This particular oxygenator technology dominated the industry for 25 years until more suitable membrane oxygenators evolved.

Despite the preferred use of the DeWall-Lillihei bubble oxygenator during the infancy of cardiac surgery, there were other groups developing oxygenators for the pediatric population. One group (Rashkind and Dorson) progressed oxygenator technology in pediatric patients suffering from respiratory distress. They recorded the earliest attempts at extracorporeal respiratory support in infants. ${ }^{23,24}$ In 1965 , this group used a simple, pump-less disposable plastic device, with a total priming volume as low as $30 \mathrm{~mL}$, to study its use in canine and human subjects. They studied four children with respiratory insufficiency secondary to cystic fibrosis treated with the extracorporeal lung (Figure 3).

With the advances made by the Rashkind group and the discovery of synthetic polymers known as silicones, the pediatric oxygenator developed beyond a direct blood-gas interface. The chemical behavior and biocompatibility of a blood contact surface coated with the silicone substance proved desirable since it exhibited stable bonding with low surface tension and a lack of toxicity, and ultimately proved to be the backbone of medical device applications. Silicone became the most practical substance for coating biomaterials. ${ }^{25}$ With the use of silicone and the continued advancement of membrane technology, these two elements helped fuel the advancement of the pediatric membrane oxygenator.

The initial use of extracorporeal technology in children has led to development toward more superior pediatric membrane oxygenator technology. The purpose of this review is to analyze the medical and scientific literature in regard to examining the development of the pediatric membrane oxygenator 


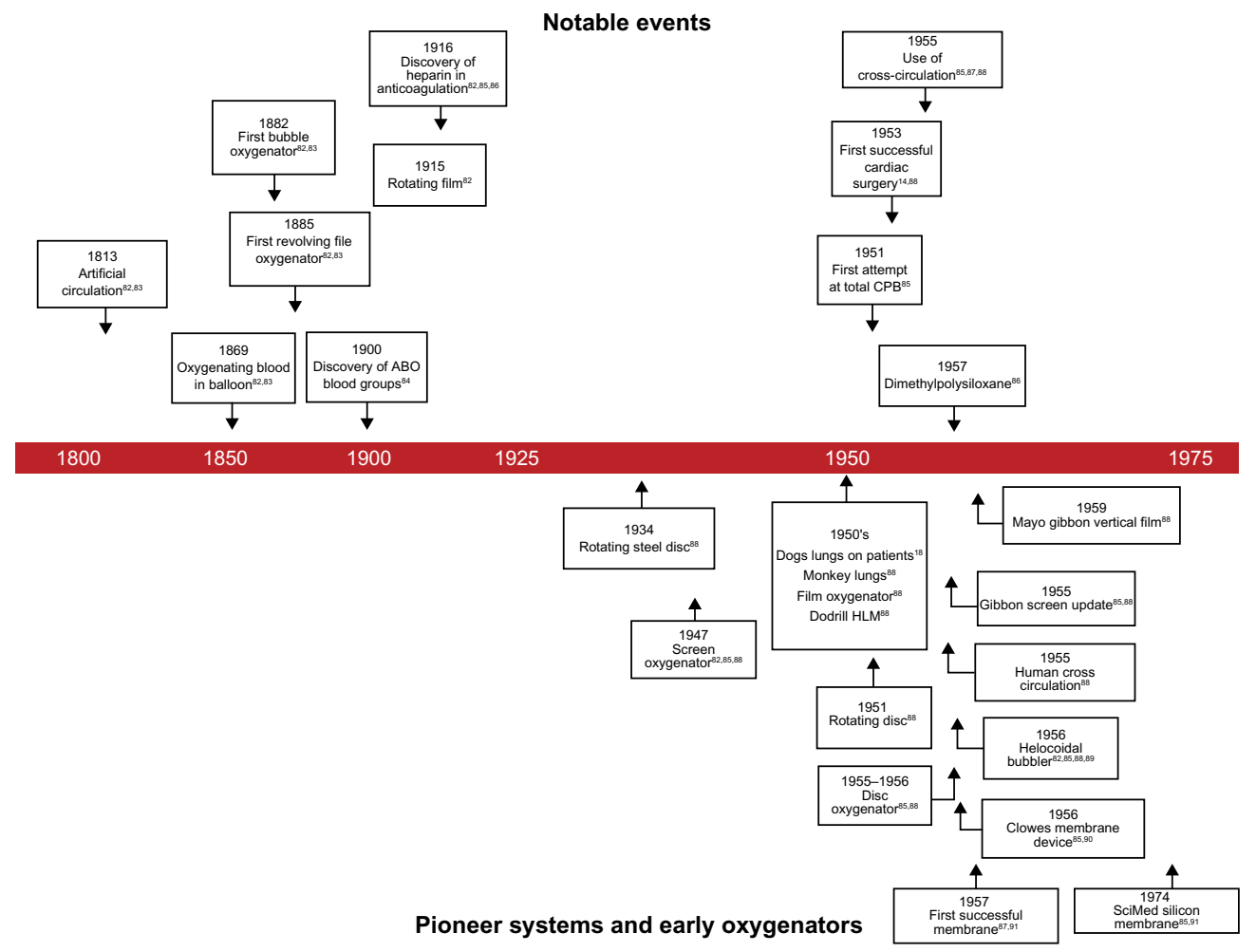

Figure 2 Historical events, pioneer systems and early oxygenators.

from its conceptual evolutionary stages to artificially supporting whole body perfusion in the pediatric setting.

\section{Foundations of the pediatric membrane oxygenator}

In 1944, Kolff and Berk made an observation about blood oxygenation during renal dialysis involving cellophane tubes. They recognized that cellophane, being semipermeable over a microporous surface, was able to transfer oxygen. This discovery launched the initial investigation into the development of a membrane oxygenator. ${ }^{26}$
In the period 1955-1957, the first successful membrane oxygenator was developed by Clowes et al using sheets of polyethylene as a membrane. Named the Clowes handmade membrane device, it had a low but definite permeability to oxygen and carbon dioxide and contained a large surface area. It was used in cardiac surgery in $1956.27,28$ In 1957, Kammermeyer reported development of a dimethylpolysiloxane membrane material that allowed oxygen and carbon dioxide to be transferred at a rate ten times faster than other plastics of the same time period..$^{29}$ Groups led by Kolobow, Landé, Pierce, and others used this new plastic (called silicone

Table I Open heart surgery using cardiopulmonary bypass, 195I-1953

\begin{tabular}{|c|c|c|c|c|c|c|}
\hline Surgeon & Patients (n) & Age & Defect & Method & Year(s) & Survived/mortality \\
\hline Dennis & 2 & $6-8$ years & $\begin{array}{l}\text { Atrial septal defect, } \\
\text { atrioventricular canal defect }\end{array}$ & Filming & $|95|$ & $0 / 2$ \\
\hline Gibbon & 6 & 15 months to 18 years & $\begin{array}{l}\text { Patent ductus arteriosus, } \\
\text { atrial septal defect, } \\
\text { ventricular septal defect }\end{array}$ & Filming & $1952-1953$ & $\mathrm{I} / 5$ \\
\hline Helmsworth & I & 4 years & Atrial septal defect & Bubble & 1952 & $0 / 1$ \\
\hline Dodrill & I & 16 years & Pulmonary valve stenosis & Autogenous lung & 1953 & $0 / 1$ \\
\hline Mustard & 5 & 10 months to II years & Tetralogy of fallot & Donor biological lung & $195 \mid-1953$ & $0 / 5$ \\
\hline Clowes & 3 & Neonate to 55 years & $\begin{array}{l}\text { Lung disease, aortic valve } \\
\text { stenosis, left atrial myxoma }\end{array}$ & Bubble & 1953 & $0 / 3$ \\
\hline Total & 18 & & & & & I/ 88 (94.4\% mortality) \\
\hline
\end{tabular}

Note: Data from various studies. ${ }^{12-22}$ 


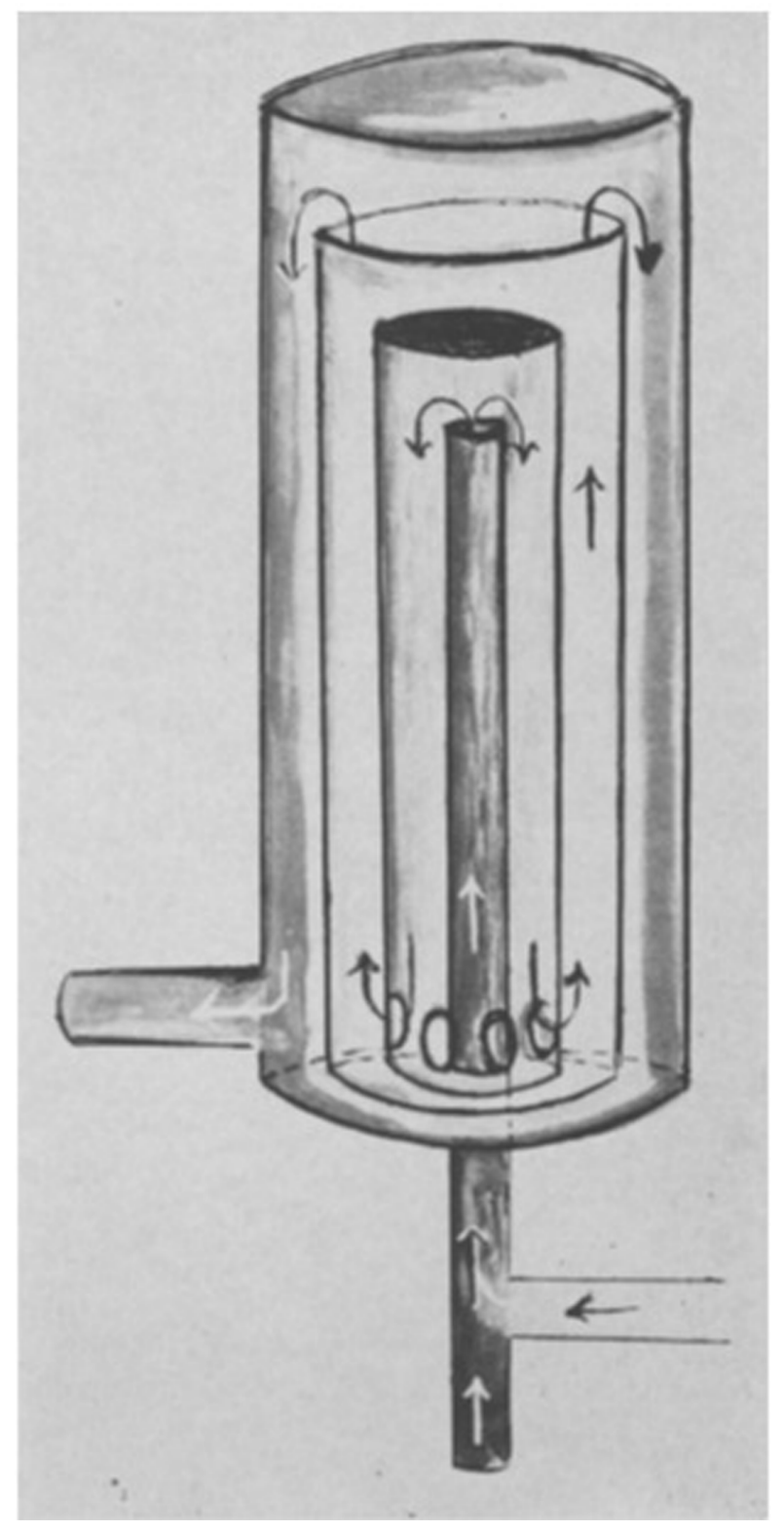

Figure 3 Diagram of the Rashkind oxygenator.

Note: Reprinted from The Journal of Pediatrics, 66, Rashkind WJ, Freeman A, Klein D, Toft RW, Evaluation of a disposable plastic, low volume, pumpless oxygenator as a lung substitute, 94-102, Copyright (C) 1965, with permission from Elsevier. ${ }^{23}$

rubber) to develop blood oxygenators that were more hemocompatible and efficient at gas exchange..$^{30-33}$

The initial investigative work with membrane oxygenator technology coincided with significant growth in cardiac surgery, cardiac catheterization, and radiographic heart and coronary circulation imaging techniques. These simultaneous advancements allowed for rapid progression in performing human open heart surgery.

In the 1960s, research began on prolonged extracorporeal circulation in the laboratories of Kolobow, Pierce, Galletti, Bramson and Hill, Landé, Drinker, Bartlett, and others internationally. ${ }^{30-35}$ In 1969, Dorson et al reported the use of a membrane oxygenator for CPB in infants. ${ }^{24}$ Their paper marked the initial contribution that membrane oxygenators were making in the management of patients with congenital heart disease.

The commercially available membrane oxygenators that were used in cardiac surgery from 1960 to 1970 were the Landé-Edwards, Travenol Modulung, and Sci-Med Kolobow devices (Figure 4). These devices were widely used in the adult sector in that, even though they had little clinical evaluation, they demonstrated reliable outcomes; however, in the pediatric sector, clinical evaluation was imperative in determining if the technology could be used for children. Along with adult cardiac surgical evaluations, the use of the membrane oxygenator within the extracorporeal perfusion circuit enhanced utilization in pediatric cardiac surgical procedures since positive clinical outcomes were observed as the direct blood-to-gas interface was eliminated. However, the membrane oxygenator was delayed in clinical application for the neonatal and pediatric populations until continued positive outcomes were demonstrated in the adult patient population.

Prior to introduction of the membrane oxygenator into perfusion practice, the bubble oxygenator was the primary device for perfusion services. Clark et al, Sugg et al, and Baffes et al helped transition extracorporeal circulation from the bubble era to the membrane era. They reported the first palliative extracorporeal membrane oxygenation procedures in infant cardiac surgery. ${ }^{36-39}$ To accomplish the goal of transitioning from the use of the bubble oxygenator to the membrane oxygenator during cardiac surgery, improved materials were needed. With the realization that hydrophobic materials were performing poorly in regard to gas exchange and preservation of blood components during operative procedures, the concept of a hydrophilic material for oxygenator technology was initially examined by Fatt and LaForce. ${ }^{40}$ Use of a hydrophilic material allowed for improved gas exchange and preservation of blood components. Although their research would prove useful for future application, their products were not commercially available.

The next stage in advancing the membrane oxygenator was to investigate the benefits of a microporous material that allowed for improved gas exchange. The microporous membrane oxygenator was investigated using the hydrophobic material Teflon with a controlled pore size supported by either a screen or non-woven material, both of which proved to be more reliable materials than silicon rubber. ${ }^{41}$ Travenol Company and Baxter Corporation worked with Leonard, Wolf, and others in investigating the application of this material. These investigators developed the Modulung design. This design led to the production of the first commercially available microporous membrane oxygenator, 


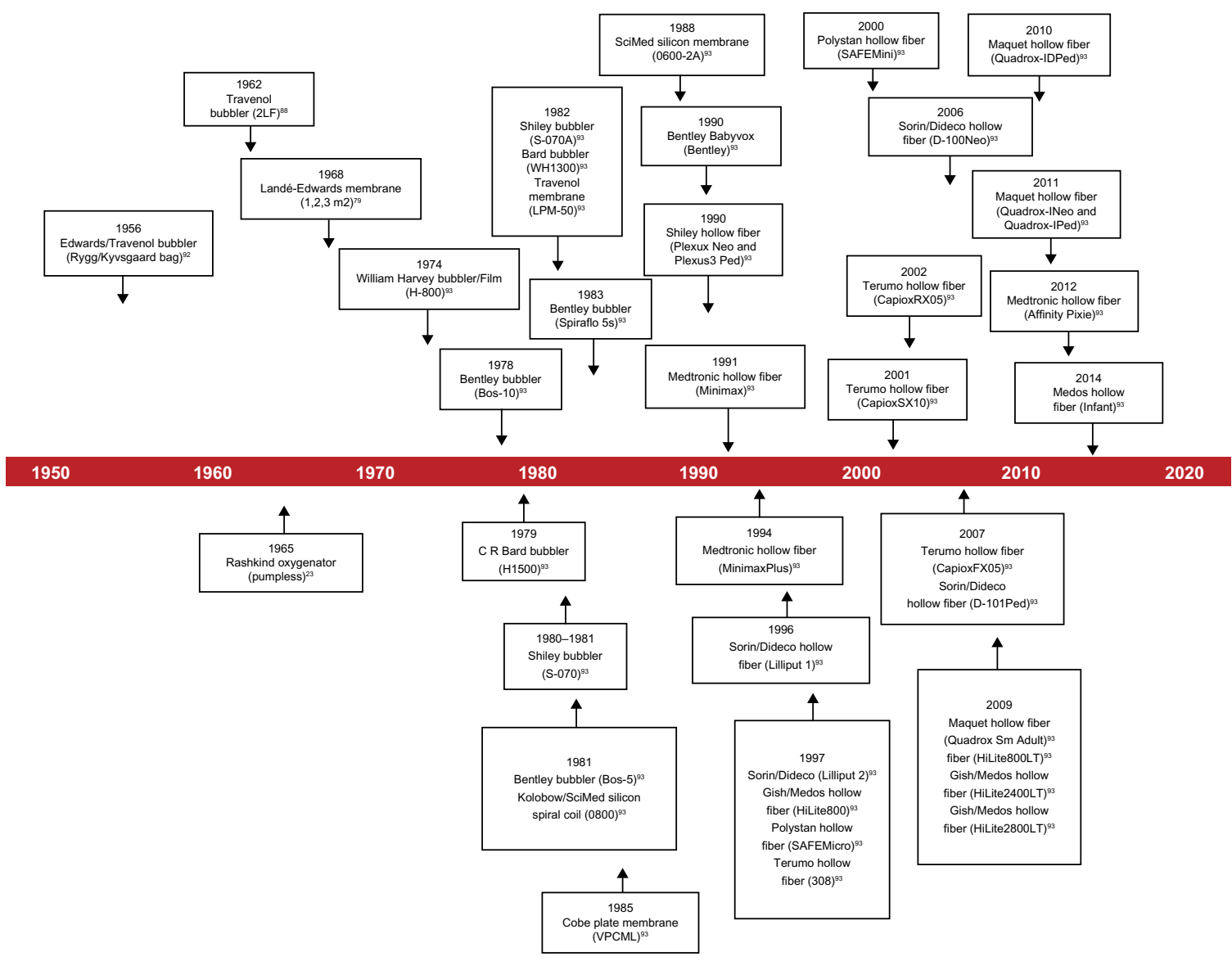

Figure 4 Chronological order of the advancement of oxygenator technology.

ie, the Travenol Membrane Oxygenator (TMO, Figure 5). The TMO device consisted of a blow-off type manometer (to avoid pressurization and gaseous emboli), a built-in heat exchanger, and a two-pump system to mimic normal cardiac circulation. ${ }^{42}$ The TMO device was developed for use in the operating room.

A different membrane was developed by Celanese Corporation. It was made of polypropylene, a stronger and more controlled material that was less likely to shift during surgery.
During this same period, Cobe Laboratories introduced a plate membrane oxygenator named the Variable Prime Cobe Membrane Lung (VPCML) (Figure 6). The VPCML oxygenator contained a rigid venous reservoir, or open system, and a segmented oxygenator flow capability that allowed for three separate prime volumes. ${ }^{41}$ The VPCML was developed solely for use in the operating room.

Sci-Med Corporation continued this trend and produced the Kolobow silicone rubber membrane oxygenator, and the cardiac
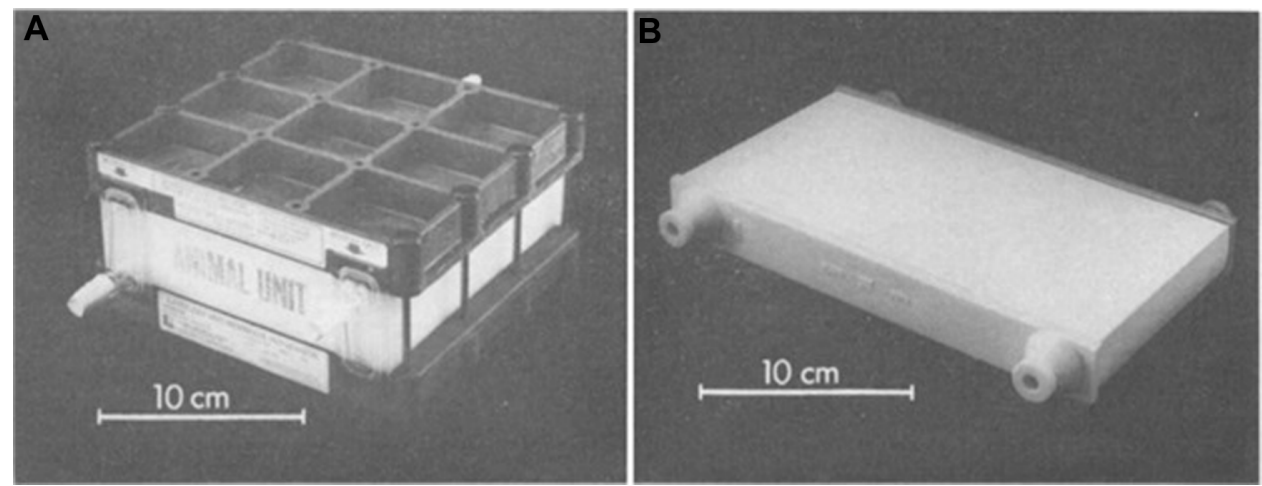

Figure 5 Landé-Edwards (A) and Travenol (B) pediatric membrane oxygenator.

Note: Reprinted from The Annals of Thoracic Surgery, Volume I4 (2), Housman LB, Braunwald NS, Experimental evaluation of the Travenol and Landé-Edwards membrane oxygenators for use in neonate perfusions, Pages 150-158, Copyright (1972), with permission from Elsevier. ${ }^{94}$ 


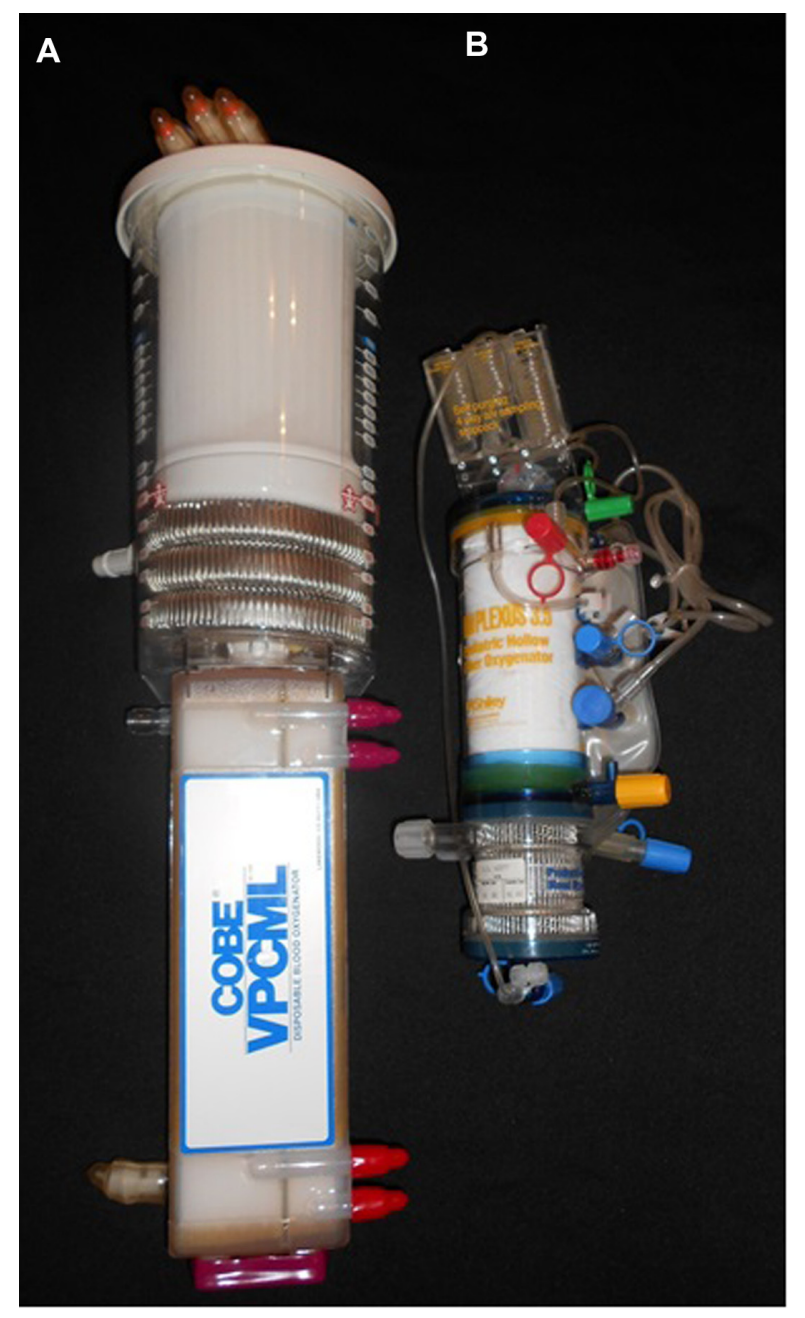

Figure 6 (A) Variable Prime Cobe Membrane Lung and (B) Shiley Plexus 3.5. Note: Courtesy of Sorin Cardiovascular INC., Arvada, CO, USA.

surgical market started to make the transition from the bubble oxygenator to utilizing membrane technology in the operating room. ${ }^{41}$ The Kolobow oxygenator was initially developed solely for extracorporeal membrane oxygenation (ECMO); however, its use transitioned to the operative setting simultaneously as that of Cobe Laboratories introduction of the VPCML model.

Searle developed a rotating membrane oxygenator device that did not generate much interest. Bramson developed the Interpulse membrane oxygenator which utilized a vortexgenerating principle. ${ }^{43,44}$ The Interpulse membrane oxygenator failed to capture interest due to a large prime volume that required additional homologous packed red blood cells and fresh frozen plasma to overcome hemodilution.

The failure of the Searle and Bramson membrane oxygenators, combined with the introduction of lower prime volume bubble oxygenators and the increased cost of the membrane oxygenators, deterred perfusionists from solely using the membrane oxygenator. ${ }^{43}$
As membrane oxygenator technology advanced, the heat exchanger device (the component of CPB that allows for regulation of perfusate temperature) was incorporated within the oxygenator design, rather than outside as a separate component within the CPB circuit. When the heat exchanger was evaluated as a separate component, it was found that there needed to be smaller prime volumes with fewer complications with regard to reduced incidence of air emboli, blood clotting, and risk for hemolysis.

Heat exchanger technology was initially advanced with the VPCML device, where the heat exchanger was placed within the venous reservoir. This placement in the reservoir helped reduce the prime volume of the CPB circuit. In later models, the heat exchanger became smaller in size and was placed initially adjacent to the membrane oxygenator and then eventually within the membrane oxygenator. The alteration to place the heat exchanger within the membrane oxygenator was to help further reduce prime volume. Thus, the external stainless steel and disposable plastic heat exchangers were ultimately eliminated because more efficient devices could be integrated into the membrane oxygenator as an integrated unit. The design of the heat exchanger within the membrane oxygenator compartment helped further advance the development of other components of the membrane oxygenator.

\section{Development of hollow fiber technology for the pediatric membrane oxygenator}

Hollow fiber technology allowed for capillaries to be stretched and formed into a compartment that allowed for more optimal gas exchange while reducing the overall surface area of the membrane oxygenator. In 1973, Kaye et al and Dow Chemical initially produced hollow fiber oxygenators using silicone tubes that proved to be inadequate due to the size and activation of the blood coagulation system over the tube header. ${ }^{44}$ Further development by Mitsubishi Rayon produced microporous hollow fiber capillaries using fiber spinning technology. Terumo Cardiovascular Systems used hollow fiber capillaries in their membrane oxygenator, which was modeled after their renal dialysis system. ${ }^{41}$

Initially, Terumo Cardiovascular Systems and Bentley Laboratories produced hollow fiber membrane oxygenators with blood flow through the hollow fiber capillary. Clinical investigation revealed undesired hemolysis and trauma to the cellular structures, with having blood flow inside the hollow fiber capillary tubes as opposed to outside of the tubes. Research and development showed that a design featuring the gas phase inside the semipermeable tube and blood 
outside of the tube was more suitable for preserving blood and formed elements. Along with Terumo Cardiovascular Systems, Celanese Ltd also produced microporous capillaries. Celanese Ltd helped further the methodology of this product by using their spinning technique and stretching the polypropylene tubes. ${ }^{41}$ This method reduced the overall surface area of the oxygenator, which reduced the amount of hemodilution and produced improved gas exchange. The key engineers responsible for the initial inclusion of the hollow fiber design into the manufacturing industry were Raibles from Bentley Laboratories, Elgas from Cobe Laboratories, and Curtis from Shiley Laboratories.

With the development of hollow fiber technology, the transition from bubble oxygenators to membrane oxygenators rapidly advanced. According to a market analysis in 1984, approximately 300,000 membrane devices were sold annually worldwide. ${ }^{45}$ In 1986 , Kolobow et al predicted the annual use of the membrane oxygenator was around $60 \%$ of all CPB procedures in the USA. ${ }^{46}$ By the 1990s, this figure rapidly approached $100 \%$. As the manufacturing sector recognized the improved clinical outcomes of the membrane oxygenator, the bubble oxygenator was discontinued. During the time period 1970-1990, many institutions made the shift to membrane oxygenators. Along with the shift to membrane oxygenators, the pediatric perfusion community was using membrane oxygenators to help reduce hemodilution, complement activation, and blood product usage in smaller sized patients (Table 2). Currently, the hollow fiber membrane oxygenator controls the sector of extracorporeal circulation within pediatric cardiac surgery. ${ }^{41}$

\section{Modern era of pediatric hollow fiber membrane oxygenator technology}

The development of hollow fiber technology allowed for advancement of the pediatric membrane oxygenator. Representation from corporations such as Shiley Laboratories, CR Bard, Cobe Cardiovascular, Sorin Group, Polystan, Gish, Medos, Dideco, Terumo Cardiovascular Systems, Maquet Cardiovascular, and Medtronic were responsible for developing the pediatric membrane oxygenator over the past 25 years (Table 3 ).

Table 2 Comparison of adult and pediatric physiology with regard to cardiopulmonary bypass

\begin{tabular}{lll}
\hline & Adult & Pediatric \\
\hline Estimated blood volume & $65-70 \mathrm{~mL} / \mathrm{kg}$ & $<10 \mathrm{~kg} 80 \mathrm{~mL} / \mathrm{kg}$ \\
& $(4.5-5.0 \mathrm{~L}$ at $70 \mathrm{~kg})$ & $(240 \mathrm{~mL}$ at $3 \mathrm{~kg})$ \\
Hemodilution effect & $25 \%-33 \%$ & $100 \%-200 \%$ \\
Oxygen consumption & $2-3 \mathrm{~mL} / \mathrm{kg} / \mathrm{min}$ & $6-8 \mathrm{~mL} / \mathrm{kg} / \mathrm{min}$ \\
Blood flow rate & $50-75 \mathrm{~mL} / \mathrm{kg} / \mathrm{min}$ & $150-200 \mathrm{~mL} / \mathrm{kg} / \mathrm{min}$ \\
Mean pressure & $50-80 \mathrm{mmHg}$ & $20-50 \mathrm{mmHg}$ \\
$\mathrm{PaCO}_{2}$ & $30-45 \mathrm{mmHg}$ & $30-80 \mathrm{mmHg}$ \\
\hline
\end{tabular}

Abbreviation: $\mathrm{PaCO}_{2}$, partial pressure of carbon dioxide.

Table 3 Chronological order of FDA approved membrane oxygenators utilized for the pediatric population

\begin{tabular}{|c|c|c|c|}
\hline Company & $\begin{array}{l}\text { Oxygenator } \\
\text { type }\end{array}$ & Model & $\begin{array}{l}\text { Surface area } \\
\left(\mathrm{m}^{2}\right)\end{array}$ \\
\hline Landes/Edwards & Silicone rubber & Landes/Edwards & I.0, 2.0, and 3.0 \\
\hline Kolobow/Sci Med & Silicone rubber Spiral wound flat sheet & $0400-2 A, 0600-2 A, 0800-2 A, 1500-2 A$ & $0.4,0.6,0.8$, and $\mathrm{I} .5$ \\
\hline Travenol & Fan folded flat sheet membrane & Modulung (TMO) Pediatric & 1.12 \\
\hline Cobe & Plate membrane & VPCML & $0.4,0.85$, and 1.25 \\
\hline Shiley & Hollow fiber & Plexus $2 \mathrm{Neo} / 3 \mathrm{Ped}$ & $0.42,0.62$, and $\mathrm{I} .0$ \\
\hline Bentley & Hollow fiber & Univox & 1.8 \\
\hline Bentley & Hollow fiber & Babyvox & 0.8 \\
\hline Medtronic & Hollow fiber & Mini Max (Plus) & 0.8 \\
\hline Terumo & Hollow fiber & 308 & 0.8 \\
\hline Terumo & Hollow fiber & 320 & 2.0 \\
\hline Sorin/Dideco & Hollow fiber & Lilliput D90I/D902 & 0.34 \\
\hline Gish/Medos & Hollow fiber & Hilite 800 & 0.6 \\
\hline Polystan & Hollow fiber & Safe Micro/Mini & 0.33 and 0.6 \\
\hline Terumo & Hollow fiber & Capiox SXIO & 1.0 \\
\hline Terumo & Hollow fiber & Capiox RX05/RXI5 & 0.5 and $I .5$ \\
\hline Sorin/Dideco & Hollow Fiber & DI00/DIOI & 1.0 \\
\hline Terumo & Hollow fiber & Capiox FX05/FXI5 & 0.5 and 1.5 \\
\hline Maquet & Hollow fiber & Quadrox Small Adult & 1.3 \\
\hline Gish/Medos & Hollow fiber & HiLite 1000/2400/2800 & $0.39,0.65$, and 0.8 \\
\hline Maquet & Hollow fiber & Quadrox I Neonatal/Pediatric & 0.7 and $I .5$ \\
\hline Medtronic & Hollow fiber & Affinity Pixie & 0.67 \\
\hline
\end{tabular}

Abbreviations: TMO, Travenol membrane oxygenator; VPCML, Variable Prime Cobe Membrane Lung; FDA, US Food and Drug Administration. 
The initial hollow fiber pediatric membrane oxygenators that were available were the Shiley Plexus 2 and Plexus 3.5 devices (Figure 6). Both of these devices were able to accommodate the smaller pediatric population. Each of these devices had a considerably low prime volume and contained a biocompatible coating called Carmeda. The Carmeda coating was developed as a non-leaching, heparin-bonded component that helped maintain blood compatibility. A benefit from utilizing Carmeda was shown through its ability to reduce the level of leukocyte activation. ${ }^{47}$

Shortly after the release of the Plexus 2 and Plexus 3.5, Medtronic introduced the Minimax and Minimax Plus hollow fiber pediatric membrane oxygenators. The Minimax Plus also utilized Carmeda coating. These two devices were the first pediatric membrane hollow fiber oxygenators that incorporated the concept of a blood flow pathway outside of the capillary tubes. This design permitted blood flow to encompass the outside of the polypropylene fibers and allowed for enhanced gas exchange and reduced prime volume when compared with earlier models. The Minimax design helped pave the way for future pediatric hollow fiber membrane oxygenators.

During the late 1990s, the development of the Cobe Cardiovascular D901 Lilliput 1 and D902 Lilliput 2 (Sorin Cardiovascular Inc., Arvada, CO) helped change the ability to provide more optimal care for pediatric patients. These two products minimized the prime volume for the neonatal and pediatric patient populations. These two oxygenators were equipped with reduced surface areas, small tubing connections, a distinctive heat exchanger configuration, and unique recirculation ports. A new biocompatible surface modification named Phosphorylcholine Inert (PhISIO) was introduced with this device. The PhISIO coating provides a hydrophilic and hydrophobic surface that allows positive and negative charges to be balanced. ${ }^{48}$ Several studies show the benefit of utilizing these oxygenators with a biocompatible surface to reduce complement activation, platelet activation, and fibrinogen deposition. ${ }^{49-51}$

Competition to capture the pediatric perfusion community fueled Terumo Cardiovascular Systems to develop and launch the SX series oxygenator (Terumo Corporation). This membrane oxygenator was equipped with a microporous polypropylene and hollow fiber design with an inclusive stainless steel heat exchanger. Along with the housing being made of polycarbonate, the oxygenator was coated with a biocompatible surface called X-Coating. This biocompatible coating was developed as an amphiphilic biopassive polymer that developed a thin membrane on the tubing which helped to repel blood components. ${ }^{52}$ With these features, the goal of this oxygenator was to provide support for middle to larger sized pediatric patients.

Further development was done by Terumo Cardiovascular Systems through their RX series product (Terumo Corporation, Tokyo, Japan). This membrane oxygenator was equipped with the same housing and components of the SX series but had a different heat exchanger design, altered hollow fiber placement, and size reduction. ${ }^{53}$ This oxygenator further allowed minimization of the CPB circuit size due to its impressive reduction in prime volume in its time period. The benefits of this device included reduced hemodilution and decreased utilization of blood products. ${ }^{54}$

The emphasis on minimizing prime volume and maintaining safety needs was shown in the development of the Dideco KIDS D100 and D130 (Sorin Cardiovascular Inc., Arvada, $\mathrm{CO}$ ). These products were the next generation of models from the Sorin Group that proved to be greatly innovative from the previous Lilliput design. The intention of each of these membrane oxygenators was to reduce surface area while utilizing a circumferential blood flow pathway. This new blood pathway allowed for minimized prime volume with the oxygenator. ${ }^{55}$ Along with using PhISIO, the heat exchanger within the oxygenator compartment was unique for its time. The KIDS D100 advanced the ability of cardiac surgery groups to perform bloodless cardiac surgery on the smallest of patients. ${ }^{56}$

A breakthrough in pediatric membrane oxygenator technology took place with the introduction of integrated arterial line filtration (IALF). Prior to the development of this feature, a clinician placed an external arterial line filter after the oxygenator in order to provide filtration to the CPB perfusate prior to the blood returning to the patient. In several studies, the IALF has been demonstrated to help reduce microemboli. ${ }^{57-59}$ This technological advancement enabled the clinician to minimize the prime volume of the CPB circuit and maintain safety.

Terumo Cardiovascular Systems brought the first type of IALF to market with the FX series hollow fiber pediatric membrane oxygenator (Terumo Corporation, Tokyo, Japan). The IALF surrounded the hollow fiber membrane oxygenator with a separate semipermeable membrane, which allowed gaseous microemboli to be captured and diffused by using the pressure difference within the oxygenator compartment. The FX series oxygenator was the same design as the Terumo RX series with the addition of the IALF. The FX series included three different size products, two of which were developed to be used in the pediatric community. ${ }^{60}$ 

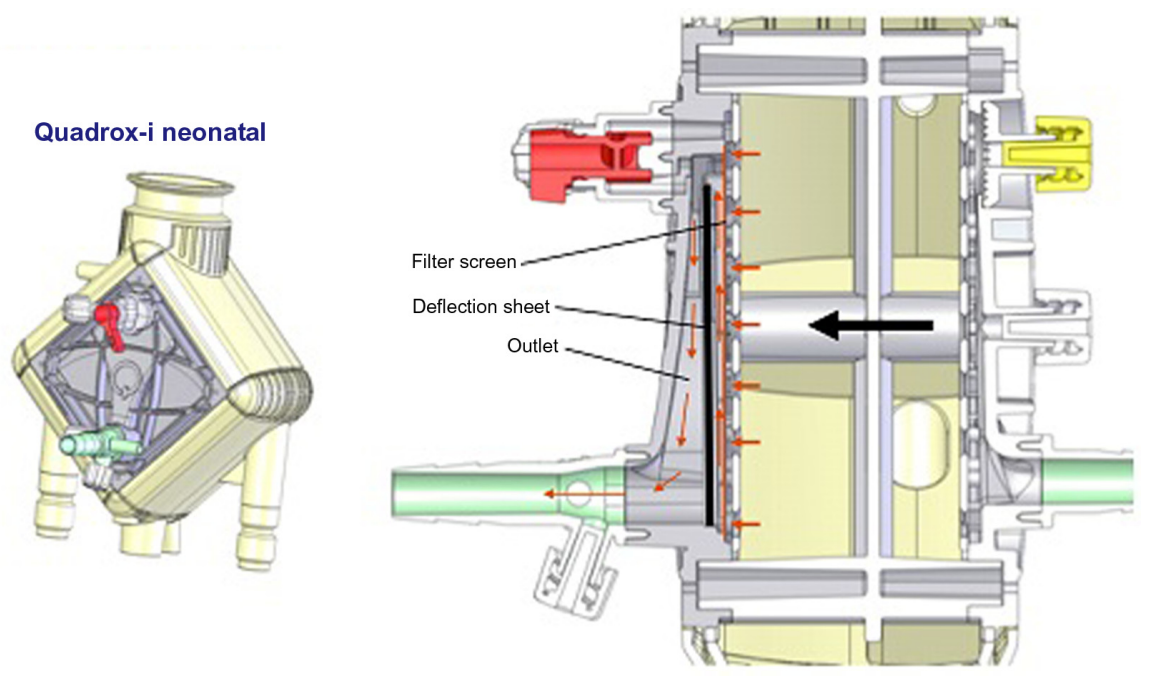

Figure 7 Quadrox-i neonatal oxygenator displaying integrated arterial line filtration. Note: Courtesy of Maquet Cardiopulmonary AG, Hirrlingen, Germany.

The Quadrox I pediatric membrane oxygenator (Maquet Cardiopulmonary AG, Hirrlingen, Germany) was developed in 2011 and included the IALF (Figure 7). This design was built with neonatal and pediatric versions. The Quadrox I was constructed as a stacked membrane rather than winding the fibers into a bundle (like previous hollow fiber membrane oxygenators). The crosswise design of the membrane fibers allowed for a decreased level of fiber overlapping and allowed for optimized surface area gas exchange. The stacked membrane design had a square structure that was different than many of the models from the previous 15 years of pediatric oxygenator design. ${ }^{61}$ This product was shown clinically to reduce the membrane pressure gradient ${ }^{62}$ and to provide gaseous microemboli protection. ${ }^{63}$

In early 2012, Medtronic launched the Affinity Pixie (Medtronic Perfusion Systems, Brooklyn Park, Mn) which is a pediatric membrane oxygenator that had a revolutionary design structure. This new membrane oxygenator was equipped with a graduated fiber bundle density design and allowed for a radial-radial blood flow path. This design allowed for efficient gas transfer, a low pressure drop, reduced prime volume, and uniform blood flow throughout the fiber bundle. Along with this innovative oxygenator design, the product had two biocompatible coating options, ie, Carmeda and Balance Biosurface. The Balance Biosurface provided a hydrophilic coating specialized for platelet preservation. ${ }^{64}$

\section{Elements of safety}

Emerging technologies with regard to the pediatric membrane oxygenator have been shown to be rewarding in terms of patient care over the past several decades. Through the triumphs of this technology, complications have occurred with its evolution. In general, there were complications regarding the incidence of hemolysis, air embolism, bloodto-water interface reactions, and other adverse events.

The negative effects with regard to blood components that were experienced during advancement of the pediatric membrane oxygenator contributed to pathophysiological changes in blood flow within artificial surfaces of the early extracorporeal perfusion systems. Blood flow changes, whether laminar, shear, or turbulent, can impose stress on blood and formed elements, specifically concerning their respective cell membranes. Each blood component can be damaged when flowing through synthetic devices, and it is critical to understand the response of the entire hematological system to such conditions. ${ }^{65}$ Studies have shown that prolonged contact with synthetic devices expose the blood to potential deleterious effects causing lysis and post perfusion anemia. ${ }^{66,67}$ Erythrocytes were the focus of the majority of initial investigations for the obvious purpose of ensuring adequacy of oxygen transport; however, the coagulation system was concurrently investigated for fibrinolysis and fibrin deposition along with platelet consumption. ${ }^{68-70}$ These studies were among the first to investigate platelet function and survivability during extracorporeal circulation. At the same time, other researchers focused attention on the alterations to leukocytes, revealing the earliest reports of profound trauma and fragility. ${ }^{71,72}$ In 1976, McIntire et al presented their findings at the annual meeting of the American Society for Artificial Internal Organs, showing significant decreases in the ability of sheared leukocytes to migrate through a Millipore filter (3 nanometer mean pore size) either randomly 
or in response to an attractive antigen (casein). ${ }^{73}$ In 1971 , Varco reported on investigative research on the behavior of gas layers and blood flow in a dynamic environment in an attempt to study the response of blood cells and surface interaction. ${ }^{74}$ The above series of scientific works has resulted in the development of: a bioactive coating to reduce cell damage, consumption, and adhesion; a need to reduce the amount of air-blood interface during extracorporeal circulation; and techniques to overcome such barriers, promoting safety and atraumatic extracorporeal devices. The negative effects on blood components did not just pertain to the oxygenator, but to all portions of the extracorporeal circuit. The advancement of the oxygenator device continues to help support the reduction in damage to blood components.

Concurrent with cell responses to membrane oxygenators, microembolization was investigated in the hope of reducing the amount of emboli occurring during $\mathrm{CPB}$. The microporous Teflon membrane oxygenator was identified by several investigative studies to be the preferred device to reduce this adverse sequela. ${ }^{75-78}$ Along with utilization of better material in the oxygenator, Carlson et al confirmed reduced solid particulate and gas particulate with the use of ultrasonic detectors during $\mathrm{CPB} .{ }^{79}$

With the latest modifications to this device, there remain areas of concern with regard to the efficiency of the oxygenator and gaseous microemboli. ${ }^{80,81}$ Currently, issues with performance of the pediatric membrane oxygenator could arise in normal clinical practice, and especially when the device exceeds manufacturer recommended rated blood flow rates. If the latest devices do not exceed their manufactured rated flow limitations, then there are few complications that may occur with the structure and/or performance of the device. Future devices will entail new emerging technologies that will have to be proven to be beneficial not only to the clinician, but also to the patient. Clinicians need to be vigilant professionals not only in daily practice, but especially when introducing a new device into their clinical arena.

The latest form of the pediatric membrane oxygenator has proved to be reliable in addressing many of the previously mentioned scenarios. Particular advancements, such as the housing structure of the heat exchanger, positioning of all components within the oxygenator structure, oxygenator fiber arrangement, and IALF have helped to improve the operational use of this device during CPB.

\section{Conclusion}

From the initial ideology of Hooke and Le Gallois to the unveiling of IALF, the advancement of this technology continues to marvel humanity. Continued research and development of the pediatric membrane oxygenator will hopefully allow for improved cardiac surgical outcomes in pediatric patients. Improvement of these oxygenators will also give practitioners the ability to progress their perfusion technique. Future pediatric membrane oxygenators may provide a sleeker design, a smaller surface area, and a reduced prime volume. With all of these advancements, the ability of each practitioner to optimize care for the individual patient will be the true test to determine the next step in product development.

\section{Acknowledgments}

The authors would like to express their appreciation to all individuals who assisted with this project.

\section{Disclosure}

The authors of this manuscript did not receive any funding or preferential treatment from any manufacturing group. The information used for this project was voluntarily provided. The authors report no conflicts of interest in this work.

\section{References}

1. Hooke R. An account of an experiment made by M. Hook, of preserving animals alive by blowing through their lungs with a bellows. Philos Trans R Soc Lond. 1667;2:539-540.

2. Le Gallois M. Experiments on the principle of life: and particularly on the principle of the motions of the heart, and on the seat of this principle: including the report made to the first class of the Institute, upon the experiments relative to the motions of the heart. Philadelphia, PA: M Thomas; 1813.

3. Hoffman JI, Kaplan S. The incidence of congenital heart disease. J Am Coll Cardiol. 2002;39:1890-1900.

4. van der Linde D, Konings EE, Slager MA, et al. Birth prevalence of congenital heart disease worldwide a systematic review and metaanalysis. J Am Coll Cardiol. 2011;58:2241-2247.

5. Prevost JL, Dumas JB. [Examen du sang et de son action dans les divers phe'nome'nes de la vie]. Annales de Chimie. 1821;18:280-296. French.

6. Lobell CE. De conditionibus quibus secretiones in glandulis perficiuntur. Diss Marburgi Cattorum: typ elwerti; 1849. Latin.

7. Brown-Sequard E. [Du sang rouge et du sang noir, et de leurs principaux elements gazeuse, l'oxygene et l'acide carbonique]. Journal of Anatomy (Paris). 1858;1:95. French.

8. Ludwig C, Schmidt A. [Das Verhalten der Gase, Welche mit dem Blut durch die reizbaren Säugethiermuskel strömen]. Leipzig Berichte. 1868;20:12-72. German.

9. Lindbergh CA. An apparatus for the culture of whole organs. $J$ Exp Med. 1935;62:409-433

10. von Schröder W. [Uber die Bildungstätte des Harnstoffs]. Archiv Fur Experimentelle Pathologie und Pharmakologie. 1882;15:364-402. German.

11. von Frey M, Gruber M. [Studies on metabolism of isolated organs. A respiration-apparatus for isolated organs]. Virchows Archiv fur Physiologie. 1885;9:519-532. German.

12. Helmsworth JA, Clark LC Jr, Kaplan S, et al. Clinical use of extracorporeal oxygenation with oxygenator-pump. JAMA 1952;150: 451-453. 
13. Clowes GHA Jr, Neville WE, Hopkins A, et al. Factors contributing to the success of failure in the use of a pump oxygenator for complete bypass of the heart and lung, experimental and clinical. Surgery 1954;36: 557-579.

14. Gibbon JH. Application of a mechanical heart and lung apparatus to cardiac surgery. Minn Med. 1954;37:171-185.

15. Dennis C, Spreng DS, Nelson GE, et al. Development of a pumpoxygenator to replace the heart and lungs: an apparatus applicable to human patients, and application to one case. Ann Surg. 1951;134 $709-721$.

16. Mustard WT, Thomson JA. Clinical experience with the artificial heartlung preparation. Can Med Assoc J. 1957;76:265-269.

17. Dodrill FD, Hill E, Gerish RA. Temporary mechanical substitution for the left ventricle in man. JAMA. 1952;150:642-644.

18. Miller WG. King of Hearts: The True Story of the Maverick Who Pioneered Open-heart Surgery. New York, NY: Crown; 2000:150.

19. Romaine-Davis A. John Gibbon and His Heart-Lung Machine. Philadelphia, Pa: University of Pennsylvania Press; 1991:69.

20. Stoney WS. Pioneers of Cardiac Surgery. Nashville, Tenn: Vanderbilt University Press; 2009:105.

21. Kirklin JW. The middle 1950s and C. Walton Lillehei. J Thorac Cardiovasc Surg. 1989;98:822-824.

22. Berne RM, Cross FS, Hirose Y, Jones RD, Kay EB. Evaluation of a rotating disk-type reservoir oxygenator. Proc Soc Exp Biol Med. 1956; 93:210-214

23. Rashkind WJ, Freeman A, Klein D, Toft RW. Evaluation of a disposable plastic, low volume, pumpless oxygenator as a lung substitute. J Pediatr. 1965;66:94-102.

24. Dorson W, Jr, Baker E, Cohen ML, Meyer B, Molthan M, Trump D A perfusion system for infants. Trans Am Soc Artif Intern Organs. 1969; $15: 155-160$

25. Kipping FS. Organic derivative of silicon. Preparation of alkylsilicon chlorides. Proc Chem. Soc. 1904;20:15.

26. Kolff WJ, Berk TJ. Artificial kidney: dialyzer with great area. Acta Med Scand. 1944;117:121-134.

27. Clowes GH Jr, Hopkins AL, Kolobow T. Oxygen diffusion through plastic films. Trans Am Soc Artif Intern Organs. 1955;1:23-24.

28. Clowes GH Jr, Hopkins AL, Neville WE. An artificial lung dependent upon diffusion of oxygen and carbon dioxide through plastic membranes. J Thorac Surg. 1956;32:630-637.

29. Kammermeyer K. Silicone rubber as a selective barrier. Industrial Engineering Chemicals. 1957;49:1685-1686.

30. Kolobow T, Bowman RL. Construction and evaluation of an alveolar membrane artificial heart-lung. Trans Am Soc Artif Intern Organs. 1963;9:238-243.

31. Landé AJ. Temporary lung. Presented at the American College of Chest Physicians annual meeting, Philadelphia, PA, USA, October 28, 1971.

32. Landé AJ, Edwards ML, Bloch JH, et al. Clinical experience with emergency use of prolonged cardiopulmonary by-pass with a membrane oxygenator. Ann Thorac Surg. 1970;10:409-423.

33. Pierce EC, 2nd, Dibelius WR. The membrane lung: studies with a new high permeability co-polymer membrane. Trans Am Soc Artif Intern Organs. 1968;14:220-226.

34. Drinker PA. Progress in membrane oxygenator designs. Anesthesiology. 1972;37:242-260.

35. Bartlett RH, Isherwood J, Moss RA, Olszewski WL, Polet H, Drinker PA. A toroidal flow membrane oxygenator: four day partial bypass in dogs. Surg Forum. 1969;20:152-153.

36. Clark RE, Ferguson TB, Hagen RW, Berger PS, Weldon CS. Experimental and clinical use of an automated perfusion system and a membrane oxygenator. Circulation. 1974;50 Suppl 2:213-218.

37. Sugg WL. Membrane oxygenation for infants. Med World New. April 6, 1973.

38. Sugg WL, Fennig JS, Platt MR. Heart surgery with a membrane oxygenator in infants. J Thorac Cardiovasc Surg. 1974;67: 593-598.
39. Baffes T, Patel K, Jegathesan S. Total cardiopulmonary bypass with the Landé-Edwards membrane oxygenator. Am J Cardiol. 1972;29: 672-677.

40. Fatt I, LaForce RC. A highly permeable membrane for membrane oxygenators. Proceedings of the Institution of Electrical Engineers. 1963;5:116-117.

41. Leonard RJ. The transition from the bubble oxygenator to the microporous membrane oxygenator. Perfusion. 2003;18:179-183.

42. Carson GA, Elgas RJ, Gordon TM. Integral blood oxygenator. United States Patent 4,818,490; 1989

43. Searle Membrane Oxygenator. Publication SMO-1/5M/75. Searle Cardiopulmonary Systems Inc.; 1975.

44. Kaye MP, Pace JB, Blatt SJ, Ferguson RJ. Use of a capillary membrane oxygenator for total cardiopulmonary bypass in calves. J Surg Res. 1973;14:58-63.

45. Gaylor JDS. Membrane oxygenators: current developments in design and application. J Biomed Eng. 1988;10:541-547.

46. Kolobow T, Borelli M, Spatola R. Artificial lung (oxygenators). Artif Organs. 1986;10:370-377.

47. Høgevold HE, Moen O, Fosse E, et al. Effects of heparin coating on the expression of CD11b, CD11c and CD62L by leucocytes in extracorporeal circulation in vitro. Perfusion. Mar 1997;12(1):9-20.

48. Sorin Group. D901 Lilliput 1 and D902 Lilliput 2 specifications. Available from: http:/www.sorin.com/sites/default/files/product/ files/2014/01/15/lilliput.pdf. Accessed April 9, 2015.

49. Zimmermann AK, Weber N, Aebert H, Ziemer G, Wendel HP. Effect of biopassive and bioactive surface coatings on hemocompatibility of membrane oxygenators. J Biomed Mater Res B Appl Biomater. 2007;80:433-439.

50. Gunaydin S. Clinical significance of coated extracorporeal circuits: a review of novel technologies. Perfusion. 2004;19 Suppl 1:S33-S41.

51. De Vroege R, van Oeveren W, van Klarenbosch J, Stooker W. The impact of heparin-coated cardiopulmonary bypass circuits on pulmonary function and the release of inflammatory mediators. Artif Organs. 2005;29:490-497.

52. Terumo Cardiovascular. SX Series oxygenator specifications. Available from: http://www.terumo-cvs.com/images/products/SpecTab_ CAPIOXSX-Oxy_11-11-11.jpg. Accessed April 9, 2015.

53. Terumo Cardiovascular. RX Series oxygenator specifications. Available from: http://www.terumo-cvs.com/images/products/SpecTab CAPIOXRX-Oxy_08-11.jpg. Accessed April 9, 2015.

54. Nuszkowski MM, Deutsch N, Jonas RA, Zurakowski D, Montague E, Holt DW. Randomized trial of the Terumo Capiox FX05 oxygenator with integral arterial filter versus Terumo Capiox Baby RX05 and Terumo Capiox AF02 arterial filter in infants undergoing cardiopulmonary bypass. J Extra Corpor Technol. 2011;43:207-214.

55. Sorin Group. KIDS D100 and KIDS D101 specification. Available from: http:/www.sorin.com/sites/default/files/product/files/2014/01/15/kids. pdf. Accessed April 9, 2015.

56. Durandy Y. The impact of vacuum-assisted venous drainage and miniaturized bypass circuits on blood transfusion in pediatric cardiac surgery. ASAIO J. 2009;55:117-120.

57. Melchior RW, Rosenthal T, Glatz AC. An in vitro comparison of the ability of three commonly used pediatric cardiopulmonary bypass circuits to filter gaseous microemboli. Perfusion. 2010;25:255-263.

58. Gomez D, Preston TJ, Olshove VF. Evaluation of air handling in a new generation neonatal oxygenator with integral arterial filter. Perfusion. 2009;24:107-112.

59. Johagen D, Appelblad M, Svenmarker S. Can the oxygenator screen filter reduce gaseous microemboli? J Extra Corpor Technol. 2014;46:60-66.

60. Terumo Cardiovascular. FX Series Specifications. Available from: http://www.terumo-cvs.com/doc/819820_FXFamilyBrochure_2009. pdf. Accessed April 9, 2015.

61. Maquet Cardiovascular. Neonatal and Pediatric Quadrox Oxygenator Specifications. Available from: http://www.maquet.com/assets/ documents/product-information/QUADROX-i-Neonatal-and-Pediatric/ MCV-BR-40000301-EN-04_QUADROX-i_NeoPed_screen.pdf. Accessed April 9, 2015. 
62. Melchior RW, Schiavo K, Frey T, et al. Evaluation of the Maquet Neonatal and Pediatric Quadrox I with an integrated arterial line filter during cardiopulmonary bypass. Perfusion. 2012;27:399-406.

63. Qiu F, Guan Y, Su X, et al. Evaluation of neonatal membrane oxygenators with respect to gaseous microemboli capture and transmembrane pressure gradients. Artif Organs. 2010;34:923-929.

64. Medtronic. Affinity Pixie Oxygenator Specifications. Available from: http://www.medtronic.com/for-healthcare-professionals/productstherapies/cardiovascular/cardiopulmonary-products/affinity-pixieoxygenation-system/\#tab2. April 9, 2015.

65. Sutera SP. Flow-induced trauma to blood cells. Circ Res. 1977;41:2-8.

66. Ross JN, Alfrey CP, Lynch EC, Kennedy JH. Hematologic observations during prolonged partial left ventricular bypass. Trans Am Soc Artif Intern Organs. 1971;17:195-199.

67. Pierce EC, Corrigan JJ, Kent BB, Cate CL, Johnson RL, Dreves AE. Comparative trauma to blood in the disc oxygenator and membrane lung. Trans Am Soc Artif Intern Organs. 1969;15:33-38.

68. McKenna R, Backman F, Whittaker B, Gibson JR, Weinberg M. The hemostatic mechanism after open-heart surgery. II. Frequency of abnormal platelet functions during and after extracorporeal circulation. J Thorac Cardiovasc Surg. 1975;70:298-308.

69. Brown CH, Lemuth RF, Heliums JD, Leverett LB, Alfrey CP. Response of human platelets to shear stress. Trans Am Soc Artif Intern Organs. 1975;21:35-38.

70. Brown CH, Leverett LB, Lewis CW, Alfrey CP, Heliums JD. Morphological, biochemical and functional changes in human platelets subjected to shear stress. J Lab Clin Med. 1975;86:462-471.

71. Kusserow BK, Larrow R. Studies of leukocyte response to prolonged blood pumping-effects upon phagocytic capability and total white cell count. Trans Am Soc Artif Intern Organs. 1968;14:261-263.

72. Kusserow BK, Larrow R, Nichols J. Metabolic and morphological alterations in leukocytes following prolonged blood pumping. Trans Am Soc Artif Intern Organs. 1969;15:40-44.

73. McIntire LV, Dewitz TS, Martin RR. Mechanical trauma effects on leukocytes. Trans Am Soc Artif Intern Organs. 1976;22:444-448.

74. Varco RL. Conference on mechanical surface and gas layer effects on moving blood. Foreward. Fed Proc. 1971;30:1485-1488.

75. Clowes GH Jr. Extracorporeal maintenance of circulation and respiration. Physiol Rev. 1960;40:826-919.

76. Lee WH Jr, Krumhaar D, Derry G, et al. Comparison of the effects of membrane and non-membrane oxygenators on the biochemical and biophysical characteristics of blood. Surg Forum. 1961;12:200-202.

77. Bramson ML, Osburn JJ, Main FB, O’Brien MF, Wright JS, Gerbode F. A new disposable membrane oxygenator with integral heat exchange. J Thorac Cardiovasc Surg. 1965;50:391-400.

78. De Leval M, Hill JD, Mielke H, Bramson ML, Smith C, Gerbode F. Platelet kinetics during extracorporeal circulation. Trans Am Soc Artif Int Organs. 1972;18:355-358.
79. Carlson RG, Lande AJ, Ivey LA, et al. The Lande-Edwards membrane oxygenator for total cardiopulmonary support in 110 patients during heart surgery. Surgery. 1973;72:913-919.

80. Dogal NM, Mathis RK, Lin J, Qiu F, Kunselman A, Undar A. Evaluation of three hollow-fiber membrane oxygenators without integrated arterial filters for neonatal cardiopulmonary bypass. Perfusion. 2012;27:132-140.

81. Melchior RW, Rosenthal T, Glatz AC. An in vitro comparison of the ability of three commonly used pediatric cardiopulmonary bypass circuits to filter gaseous microemboli. Perfusion. 2010;25:255-263.

82. Lim MW. The History of Extracorporeal Oxygenators. Anaethesia. 2006;61(10):984-995.

83. Hewitt RL, Creech O Jr. History of the pump oxygenator. Arch Surg. 1966;93(4):680-696.

84. Kantha SS. The blood revolution initiated by the famous footnote of Karl Landsteiner's 1900 paper. Ceylon Med J. 1995;40(3):123-125.

85. DeWall RA. Origin of the helical reservoir bubble oxygenator heart lung machine. Perfusion. 2003;18(3):163-169.

86. Kapoor VP, Sameer G. Manuel of Extracorporeal Membrane Oxygenation (ECMO) in the ICU. Jaypee Brothers Medical, New Delhi; 2014.

87. Drummond M, Braile DM, Lima-Oliveira AM, Camim AS, Oyama RS, Sandoval GH. Technological evolution of membrane oxygenators. Braz J Cardiovasc Surg. 2005;20(4):432-437.

88. Stoney WS. Evolution of cardiopulmonary bypass. Circulation. 2009;119:2844-2853.

89. Dewall RA, Gott VL, Lillihei CW, Read RC, Varco RL, Warden HE. Total body perfusion for open cardiotomy utilizing the bubble oxygenator; physiologic responses in man. J Thorac Surg. 1956;32(5):591-603.

90. Clowes GHA Jr, Neville WE. Membrane oxygenator. In: Moore FD, Allen JG, editors. Extracorporeal circulation. Springfield: Thomas; 1958:81-100.

91. Neville WE. Membrane oxygenators and prolonged cardiopulmonary support. The Annals of Thoracic Surgery. 1971;12(5):551-553.

92. Kay P, Munsch CM. Techniques in Extracorporeal Circulation. 4th ed. Boca Raton: CRC Press; 2004.

93. 510(k) Premarket Notification [webpage on the Internet]. Silver Spring, MD: US Food and Drug Administration; 2016 [updated April 11, 2016]. Available from: http://www.accessdata.fda.gov/scripts/cdrh/cfdocs/ cfpmn/pmn.cfm?start_search $=1 \&$ Center $=\&$ Panel $=\&$ ProductCode $=\mathrm{dt}$ $\mathrm{z} \&$ KNumber $=\&$ Model $=\&$ Applicant $=\&$ DeviceName $=\&$ Type $=\&$ Third PartyReviewed $=\&$ ClinicalTrials $=\&$ ExpeditedReview $=\&$ Decision $=\&$ DecisionDateFrom $=1 \% 2 \mathrm{~F} 1 \% 2 \mathrm{~F} 1965 \& D$ DecisionDateTo $=1 \% 2 \mathrm{~F} 1 \% 2 \mathrm{~F}$ $2015 \&$ DeNovo $=\& I V D P r o d u c t s=\&$ CombinationProducts $=\& Z$ Numbe $\mathrm{r}=\&$ PAGENUM=500. Accessed April 15, 2016.

94. Housman LB, Braunwald NS. Experimental evaluation of the Travenol and Landé-Edwards membrane oxygenators for use in neonate perfusions. Ann Thora Surg. 1972;14(2):150-158.
Pediatric Health, Medicine and Therapeutics

\section{Publish your work in this journal}

Pediatric Health, Medicine and Therapeutics is an international, peerreviewed, open access journal publishing original research, reports, editorials, reviews and commentaries. All aspects of health maintenance, preventative measures and disease treatment interventions are addressed within the journal. Practitioners from all disciplines are invited to submit

\section{Dovepress}

their work as well as healthcare researchers and patient support groups. The manuscript management system is completely online and includes a very quick and fair peer-review system. Visit http://www.dovepress.com/ testimonials.php to read real quotes from published authors. 